\title{
Serologic survey of hantavirus in a rural population from the northern State of Mato Grosso, Brazil
}

\author{
Ioni Oliveira Santos ${ }^{[1]}$, Glauciane Garcia de Figueiredo ${ }^{[2]}$, Luiz Tadeu Moraes Figueiredo ${ }^{[2],}$ \\ Maria Regina Andrade de Azevedo ${ }^{[3]}$, Neil Ferreira Novo ${ }^{[3]}$ \\ and Celidéia Aparecida Coppi Vaz ${ }^{[3]}$
}

[1]. Escritório Regional de Saúde de Colíder, Secretaria Estadual de Saúde de Mato Grosso, Colider, MT. [2]. Centro de Pesquisa em Virologia, Faculdade de Medicina de Ribeirão Preto, Universidade de São Paulo, São Paulo, SP. [3]. Departamento de Pós Graduação, Universidade de Santo Amaro, Santo Amaro, SP.

\begin{abstract}
Introduction: Hantavirus is a genus of ribonucleic acid (RNA) viruses included in the family Bunyaviridae. Hantaviruses are rodent-borne zoonoses that, in the last 18 years, became an emergent public health problem in the Americas, causing a severe cardiopulmonary syndrome. This disease has no specific treatment and has a high case fatality. The transmission of hantavirus to man occurs by inhaling aerosols of rodent excreta. The aim of this study was to determine the prevalence of antibodies to hantavirus in the population of the rural settlement of Tupã in the county of Marcelândia, State of Mato Grosso, Brazil. Methods: The participants of the serologic survey were visited at their homes and selected randomly among the settlement population. Blood samples of the participants were collected by venopuncture. The serum samples were tested by an IgG-ELISA using an N recombinant protein of Araraquara hantavirus as antigen, using the protocol previously established by Figueiredo et al. Results: IgG antibodies to hantavirus were detected in $7(13 \%)$ of the 54 participants. The positivity was higher among men. It was observed that there was an association of seropositivity to hantavirus within the participants born in the south of Brazil. Conclusions: The results suggest that, in this rural area, everyone is exposed to the same risk of becoming infected with hantavirus, and, therefore, there is a need to intensify surveillance activities and education of the local people to prevent this viral infection.
\end{abstract}

Keywords: Hantavirus. Hantavirosis. Bunyaviridae.

\section{INTRODUCTION}

The north of the State of Mato Grosso, Brazil, has suffered an extensive deforestation in order to use the land for farming soybeans and corn. This area also received a large migration of agricultural workers from other parts of the country. Thus, in recent years, the north of the State of Mato Grosso became a setting for the spread of various health disorders directly related to vectors and wild hosts. These health disorders, such as malaria, leishmaniasis, and yellow fever, are considered as endemic. However, in the last decade, hantaviruses emerged in the area and took the lives of many people, mainly farm workers ${ }^{1}$.

Hantaviruses are worldwide zoonoses from wild rodents belonging to different species. These are ribonucleic acid (RNA) viruses of the family Bunyaviridae that, currently, includes more than 300 distinct viral species distributed in 5 genera: Orthobunyavirus, Phlebovirus, Nairovirus, Hantavirus, and Tospovirus ${ }^{2}$. The Hantavirus genus includes at least 45 virus species and half of them were reported as causing human disease ${ }^{3}$. Different from other Bunyaviridae, which are arboviruses, hantaviruses are maintained in nature-infecting wild rodents. Hantavirus transmission to humans occurs when these pathogens are primarily inhaled through the aerosolization of rodent excreta and contaminated secretions $\mathrm{s}^{4,5}$. The American hantaviruses, when infecting man, cause a severe hantavirus cardiopulmonary

Address to: Dr. Ioni Oliveira Santos. ERSCOL/SES/MT. Av. Costa e Silva 125, Setor Norte, 78500-000 Colíder, MT, Brasil.

Phone/Fax: 5566 3541-2757

e-mail: ionibiologo1@hotmail.com

Received in 19/07/2011

Accepted in 09/12/2011 syndrome (HCPS). In Brazil, HCPS has been reported in 1,335 patients until August 2010, and 525 of these died (39\% case fatality ratio). Hantavirus cardiopulmonary syndrome has been reported in all Brazilian regions, predominating in the south, southeast, and midwest (91.2\% of the cases) $)^{6}$. From 1999 to August 2010, 206 HCPS cases including $86(43 \%)$ fatalities were reported in the Brazilian midwestern State of Mato Grosso ${ }^{6}$. From 2007, 12 of these cases occurred in the county of Marcelândia, the place where this study was performed to investigate the circulation of hantavirus. Recently, it was described that evidence of the circulation of hantavirus in four counties were influenced by the BR-163, also known as Cuiabá-Santarém. The county of Marcelândia was contemplated in this research and presented a prevalence of $9.4 \%$ of the specific antibodies against hantavirus ${ }^{7}$.

\section{METHODS}

\section{Participants of the serologic survey}

In this serologic survey, 54 individuals participated, mostly migrants living in Tupã, a 540-inhabitants rural settlement in the county of Marcelândia, located in the north of the State of Mato Grosso, Brazil, at $11^{\circ} 05^{\prime} 22$ latitude and 54 $27^{\prime} 02$ longitude (Figure 1).

The participants were visited at their homes and selected randomly among the settlement population after giving a signed authorization. The group of participants included $61.1 \%$ males and $38.9 \%$ females. All participants answered a questionnaire, which includes personal information, education, professional activities, previous diseases, and contact with rodents. The vegetation surrounding the homes of the participants and their sources of drinking water were also analyzed. 


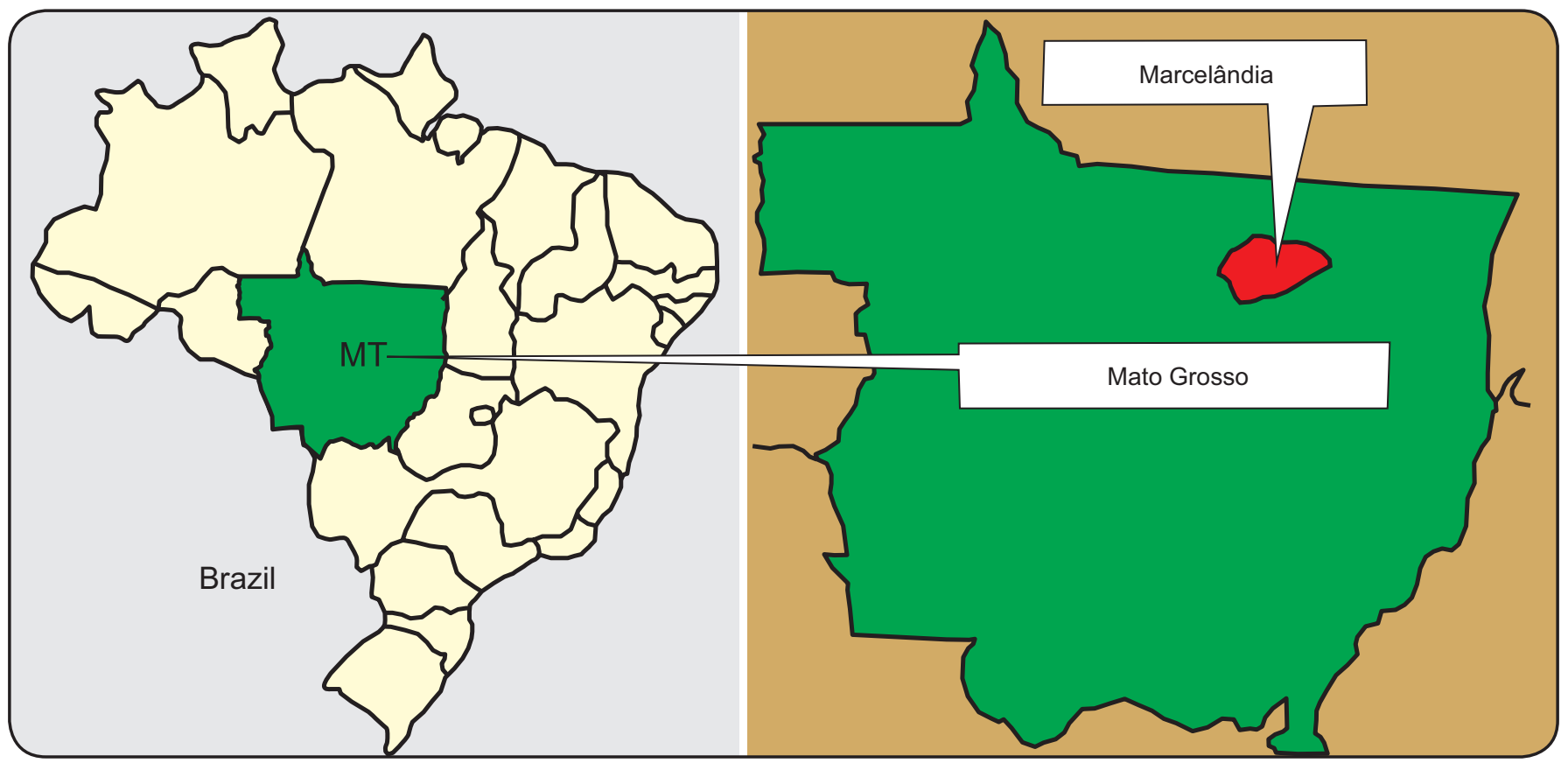

FIGURE 1 - Map of the State of Mato Grosso, Brazil, showing (in red) the county of Marcelândia.

\section{Serum samples}

Blood samples of the participants were collected by venopuncture. The sera were separated and stored at $-20^{\circ} \mathrm{C}$ in the Laboratory of Clinical Analysis of the county of Marcelândia. These samples were latterly transported, at $4^{\circ} \mathrm{C}$ and following biosafety regulations, to the Virology Research Center, School of Medicine of the University of São Paulo in Ribeirão Preto City, Brazil (VRC-SMUSP-RP).

\section{IgG-ELISA to hantavirus}

The serum samples were tested by an immunoglobulin G-enzyme linked immuno-assay (IgG-ELISA) using an $\mathrm{N}$ recombinant protein of Araraquara hantavirus as antigen in the VRC-SMUSP-RP'.

The ELISA, using the $\mathrm{N}$ recombinant protein of Araraquara hantavirus produced in Escherichia coli, was standardized using the protocol previously established by Figueiredo and collaborators ${ }^{8}$.

\section{Statistical analysis}

The chi-square test was applied to the results shown in contingency tables, and the Fisher's exact test was used to look for an association between qualitative variables of the participants and seropositivity to hantavirus. The level of significance was $5 \%(\mathrm{p}=0.05)$ for both tests 9 .

\section{Ethical considerations}

This study was approved by the National Ethics Committee of the Ministry of Health (CONEP/MS), as well as by the Ethics Committee in Research of the University of Santo Amaro/SP (144/09, May 2010).

\section{RESULTS}

All 54 participants of this study were agricultural workers referring elementary school education, doing subsistence agriculture, and living in the Tupã settlement (for 6.5 years in average). Twenty-five participants were born in the south, 12 in the midwest, 10 in the southeast, 5 in the northeast, and 2 in the north of Brazil. Most of the participants referred a previous working activity in other regions of the State of Mato Grosso, following fronts of agricultural expansion and trying to receive agriculture lands from the government.

Based on the serologic test, 7 participants had IgG antibodies to hantavirus (positivity of $13 \%$ ), as shown in Table 1 . There was no association of the gender of the participants with the seropositivity to hantavirus. Six of the 7 seropositive participants were born in the south of Brazil and 1 in the northern State of Pará, Brazil. The seropositivity among southern participants was significantly higher than in those from other regions $(\mathrm{p}=0.031)$, as shown in Table 2.

TABLE 1 - Seropositivity to hantavirus associated to gender of the participants of the study ( $n=54)$.

\begin{tabular}{lcccc}
\hline Gender & Negative & Positive & Total & Seropositivity (\%) \\
\hline Masculine & 28 & 5 & 33 & 15.1 \\
Feminine & 19 & 2 & 21 & 9.5 \\
\hline Total & $\mathbf{4 7}$ & $\mathbf{7}$ & $\mathbf{5 4}$ & $\mathbf{1 3 . 0}$ \\
\hline
\end{tabular}

Fisher's exact test $(\mathrm{p}=0.436)$

TABLE 2 - Seropositivity to hantavirus associated to the birthplace of the participants.

\begin{tabular}{lcccc} 
& \multicolumn{2}{c}{ Serologic test } & & \\
\cline { 2 - 3 } Region of birth & positive & negative & Total & Seropositivity (\%) \\
\hline South region of Brazil & 6 & 19 & 25 & 24 \\
All other regions & 1 & 28 & 29 & 3.4 \\
\hline Total & $\mathbf{7}$ & $\mathbf{4 7}$ & $\mathbf{5 4}$ & $\mathbf{1 3 . 0}$ \\
\hline
\end{tabular}

The Fisher's exact test was significant ( $\mathrm{p}=0.031)$. 
Regarding the occurrence of diseases in the participants 60 days preceding the collection of serum, fever, dry cough, headache, myalgia, and asthenia were reported by 6 participants. Three other participants referred gastrointestinal symptoms (diarrhea and vomiting). Chronic diseases, such as hypertension and diabetes, were referred by $24 \%$ of the participants. However, the occurrence of any of these signs, symptoms, or diseases was not associated to seropositivity to hantavirus.

It was observed that all participants had a basic knowledge about hantavirus. They knew about the natural reservoir, forms of contamination, severity of the hantavirus disease, and measures to prevent infection. A proportion of the participants $(59.3 \%)$ referred a previous direct contact with rodents and their excreta while $40.7 \%$ reported they do not remember or have not had such contact, as shown in Table 3. However, rodent contact was not associated with hantavirus in the previous infection. Therefore, $46.3 \%$ of the participants referred to store grains in the peridomiciliary environment and $33.3 \%$ inside of their residences, without association with seropositivity to hantavirus.

The predominant environment surrounding the homes of the participants was pasture, in $38.9 \%$, followed by poultry, in $27.8 \%$. Other vegetation surroundings were forest, manioc plantation, pineapple plantation, primary forest, and fruit orchard and the sum of these 5 environments accounted for $33.3 \%$ of the houses of the participants. There was no association of any of these environments with seropositivity to hantavirus.

Regarding the source of water used in houses by the participants, $83.3 \%$ used underground water treated with sodium hypochlorite while $16.7 \%$ used river water. It was not observed if there was an association between the type and source of water used in houses by the participants and the seropositivity to hantavirus.

TABLE 3 - Seropositivity to hantavirus associated to reference of contact with rodents by the participants.

\begin{tabular}{|c|c|c|c|c|}
\hline \multirow[b]{2}{*}{ Contact with rodents } & \multicolumn{2}{|c|}{ Serologic test } & \multirow[b]{2}{*}{ Total } & \multirow[b]{2}{*}{ Seropositivity (\%) } \\
\hline & positive & $\overline{\text { negative }}$ & & \\
\hline Yes & 6 & 26 & 32 & 18.5 \\
\hline No & 1 & 21 & 22 & 4.5 \\
\hline$\overline{\text { Total }}$ & 7 & 47 & 54 & 13.0 \\
\hline
\end{tabular}

Fisher's exact test $(\mathrm{p}=0.1315)$.

\section{DISCUSSION}

It is important to understand the distinct epidemiologic aspects related to hantavirus striking populations at risk in different regions of Brazil. This study is the first work of this nature conducted in the State of Mato Grosso, and the results could help to better understand the epidemiology of this disease in the region, helping on decision-making and implementation of appropriate public health policies for emerging diseases in the region.

The first report of HCPS in the Americas occurred in the United States of America in 1993, and this disease was also reported in Brazil of the same year ${ }^{10-13}$. These were severe
HCPS cases with fatalities that occurred in Juquitiba, State of São Paulo ${ }^{12}$. Presently, about one thousand and a half HCPS cases were reported in Brazil, and some hantaviruses and their probable rodent-reservoirs were also known. The area of Atlantic rainforest predominates the Juquitiba virus (JUQV), and its reservoir is Oligoryzomys nigripes ${ }^{14}$. The cerrado (savannah) of the southeastern countryside and of the central plateau predominates Araraquara virus (ARAV), having Necromys lasiurus as reservoir ${ }^{14,15}$. Anajatuba virus (ANAJV) causes HCPS in the swamp areas in the northeast of Brazil (State of Maranhão) and is associated to Oligoryzomys fornesii. Castelo dos Sonhos virus (CASV) and Laguna Negra virus (LNV) are both associated with cases of HCPS in Amazonian and Pantanal (swamp) ecosystems of Pará and Mato Grosso States, and associated to Oligoryzomys moojeni and Calomys callosus, respectively ${ }^{16}$. Based on the known geographic distribution, CASV could be the causative of hantavirus infections we detected in Tupã. This randomized serologic survey included $10 \%$ of the population of Tupã settlement as participants and showed that $13 \%$ of them were previously infected with hantavirus. This seroprevalence to hantavirus is almost 3 times higher than that observed in another Amazonic biome region at the State of Maranhão, 4.7\% and similar to that observed in the Jardinópolis county at the State of São Paulo ${ }^{17,18}$. This high seroprevalence to hantavirus also shows that most of these infections, especially those causing mild forms of disease, may remain undiagnosed.

It was also observed that there was a slightly higher seropositivity to hantavirus among men when compared to females as previously observed in other Brazilian hantavirus serologic surveys ${ }^{17}$. The participants of the serologic survey were mostly migrant agricultural workers from all regions of Brazil, mostly from the south, especially from the State of Paraná. It was found that seropositivity to hantavirus was significantly higher in southern participants when compared to those from other regions. Thus, seropositives could become infected by hantavirus when lived in the south, where most of the Brazilian HCPS cases occurred. However, 12 hantavirusconfirmed cases occurred in the county of Marcelândia from 2007 to 2009, which shows that local infections could also have occurred ${ }^{1}$.

In this study, it was not possible to detect any personal, morbid, or labor-related antecedent referred by the participants that could be associated to hantavirus infection. Curiously, it also included the contact with rodents and their excreta. Similar results were also observed in the previous hantavirus serologic survey in Jardinópolis county ${ }^{18}$.

No environment surrounding the homes of the participants, especially pastures that have grass seeds and food attractive of large populations of wild rodents, was associated with hantavirus infection in this study ${ }^{19}$. The source of water used in houses by the participants was also not associated with hantavirus infection ${ }^{20}$.

Briefly, we presented that there is a high prevalence of individuals infected with hantavirus in the population of a rural settlement in the north of the State of Mato Grosso. It was also suggested that all inhabitants of the settlement are exposed to 
the same risk of becoming infected with hantavirus. Therefore, there is a need to intensify surveillance activities and education of the local people to prevent this viral infection.

\section{ACKNOWLEDGMENTS}

The authors would like to thank the Secretariat of Health of the State of Mato Grosso and the Team of the Regional Office of Health of Colíder.

\section{CONFLICT OF INTEREST}

The authors declare that there is no conflict of interest.

\section{REFERENCES}

1. Santos IO. Cases of hantavirose taken care of in the period of 2007 the 2009 in the area of abrangência of the Regional Office of Health of Colíder-MT [Especialization]. [Sinop (MT)]: University of Cuiabá - Campus Airport of Sinop; 2009. $64 \mathrm{p}$

2. Schmaljohn CS, Nichol ST. In: Knipe DM, Griffin DE, Lamb RA, Straus SE, Howley PM, Martin MA, et al, editors. Fields Virology. $5^{\text {th }}$ Ed. Philadelphia: Lippincott, Williams \& Wikins; 2007. p. 1741-1789.

3. Dearing MD, Dizney L. Ecology of hantavirus in a changing world. Ann N Y Acad Sci 2010; 1195:99-112.

4. Schmaljohn C, Hjelle B. Hantavirus: a global disease problem. Emerg Inf Dis 1997; 3:95-104.

5. Ferreira MS. Hantaviroses. Rev Soc Bras Med Trop 2003; 36:81-96.

6. Ministério da Saúde. Casos e óbitos por Hantavirose por Unidade Federada Provavel de Infecção e Ano. Brasil, 1993-2010 [Internet]. Brasília: Secretaria de Vigilância em Saúde; [Cited December 2010 08]. Available from: http:// portal.saude.gov.br/portal/arquivos/pdf/casos_obitos_hantaan_uf_ano_2010. pdf/.

7. Medeiros DBA, Travassos da Rosa ES, Marques AAR, Simith DB, Carneiro AR, Chiang JO, et al. Circulation of hantaviruses in the influence area of the Cuiabá-Santarém highway. Mem Inst Oswaldo Cruz 2010; 105:665-671.
8. Figueiredo LTM, Moreli ML, Borges AA, Figueiredo GG, Badra SJ, Bisordi I, et al. Evaluation of a solid-phase enzyme immunoassay based on Araraquara Hantavirus recombinat nucleoprotein. Am J Trop Med Hyg 2009; 81:273-276.

9. Siegel SE, Castellan JR. Estatística não paramétrica para ciências do comportamento. $2^{\text {nd }}$ ed. Porto Alegre: Artmed; 2006.

10. Nichol ST, Spiropoulou CE, Morzunov S, Rollin PE, Ksiazek TG, Feldmann $\mathrm{H}$, et al. Genetic identification of a hantavirus associated with an outbreak of acute respiratory illness. Sciense 1993; 262:914-917.

11. Center for Disease Control and Prevention. Outbreak of acult illness - south western United States, 1993. MMWR 1993; 42:421-424.

12. Nichol ST. Genetic analysis of hantaviruses and their host relationships. In: Saluzzo JF, Dodet B, editors. Emergence and control of rodent-borne viral diseases. Paris: Elsevier; 1999. p. 99-109.

13. Iversson LB, Travassos da Rosa APA, Rosa MDB. Infecção humana por hantavirus nas regiões sul e sudeste do Brasil. Rev Assoc Medica Bras 1994; 40:85-92.

14. Pereira LE. Ecoepidemiologico study of hantavirus in rodents of the regions of Atlantic and Closed Mata of Brazil [master's thesis]. [São Paulo (SP)]: University of São Paulo; 2006. 207p.

15. Avsic-Zupanc TSY, Xiao R, Stojanovic A, Glicic G, Groen VD, Leduc JW. Characterization of Dobrava Vírus: a hantavirus from Slovenia, Yugoslávia. J General Virol 1992; 76:2801-2808.

16. Rosa EST. Association virus-host and molecular epidemiologia of hantavírus in distinct Amazonian ecosystems: Maranhão and Pará - Mato Grosso [master's thesis]. [Rio de Janeiro (RJ)]: Institute Oswaldo Cruz; 2008. 152p

17. Mendes WS, Silva AAM, Neiva RF, Costa NM, Assis MS, Vidigal PMO, et al. Serologic survey of hantavirus infection, Brazilian Amazon. Emerg Infect Dis 2010; 5:889-891.

18. Campos GM. Study physician-epidemiologist on hantavirose in the region of Ribeirão Preto, SP [Dissertation]. [Ribeirão Preto (SP)]: Faculdade de Medicina de Ribeirão Preto da Universidade de São Paulo; 2002. 71 p.

19. Childs JE, Krebs JW, Ksiazek TG, Maupen GO, Gage KL, Rollin PE, et al. A house hold-based, case-control study of environmental factors associated with hantavirus pulmonary syndrome in the south-western United States. Am J Trop Med 1995; 52:393-397.

20. Mills JN, Ksiasek TG, Ellis BA, Rollin PE, Nichol ST, Yates TL, et al. Patterns of association with wild hosts and habitat: antibody reactive with sin nombre virus in small mammals in the major biotic communities of the southwestern United States. Am J Trop Med Hyg 1997; 56: 273-284. 